\title{
METODE V IZOBRAŽEVANJU ODRASLIH
}

Ko razmišljamo o izobraževanju odraslih in vseživljenjskem učenju, dajemo največji poudarek vlogi učečega se in procesom učenja, $v$ katerih ta pridobiva znanje, spretnosti, se spreminja in spreminja svet okoli sebe. Razumevanje procesov učenja odraslih je pomembno zaradi omogočanja boljših razmer za samostojno učenje odraslih, pa tudi z vidika načrtovanja čim bolj učinkovitega poučevanja in uporabe metod izobraževanja. Odrasli se učijo na različne načine, zato je razumljivo, da obstaja cela paleta izobraževalnih oblik in metod izobraževanja, ki so značilne ali še posebej priporočljive za spodbujanje učenja $v$ različnih življenjskih okoliščinah. Pomembna značilnost izobraževanja odraslih, ki bo razvidna tudi iz nekaterih člankov v tej številki Andragoških spoznanj, je tudi ta, da le manjši del izobraževanja poteka $v$ formalnih okoliščinah, večinoma pa se dogaja zunaj izobraževalnih institucij. Od učitelja odraslih se pričakuje, da obvlada različne metode, ki jih lahko učinkovito uporablja $v$ izobraževanju odraslih, in pozna dejavnike, ki jih je treba upoštevati pri njihovi izbiri in uporabi. Kot izobraževalci odraslih se moramo zavedati, da je treba za učinkovit učni proces zagotoviti aktivno sodelovanje udeležencev pri učnih dejavnostih, ki jih načrtujemo, da bi ta cilj dosegli, pa bi morali skrbno načrtovati okoliščine za učenje in pri izbiri izobraževalnih oblik in metod poskrbeti za izkušnje, ki bodo omogočale doseganje želenih rezultatov. $V$ zadnji letošnji številki Andragoških spoznanj je kar nekaj člankov, ki se ukvarjajo prav s temi vprašanji.
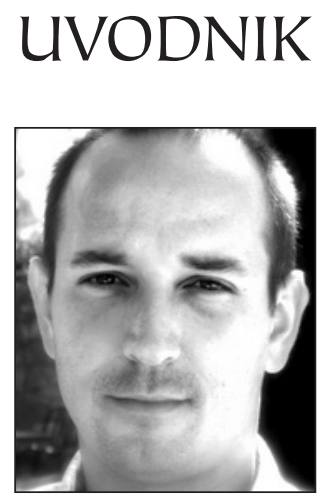

Kadar govorimo o didaktičnem delovanju učitelja, moramo razmišljati tudi o dveh pomembnih teoretičnih izhodiščih našega delovanja. Prvi je konstruktivistični pogled na poučevanje in učenje, ki ga je razvil Piaget in po katerem se učenci pojmujejo kot aktivni udeleženci učnega procesa, ki nenehno raziskujejo svet in primerjajo nove izkušnje $s$ trenutnim razumevanjem. V procesu neprekinjenega kroženja med cikli asimilacije in akomodacije se pod vplivom novih izkušenj razvija posameznikovo razumevanje naučenega. $V$ kontekstu izobraževanja to pomeni, da moramo učitelji sprejeti in upoštevati prejšnje izkušnje in znanje učencev in na tem temelju načrtovati svoje poučevanje. To je načelo, ki je v izobraževanju odraslih že dolgo sprejeto. Drugo pomembno teoretično izhodišče pa je »cona proksimalnega razvoja«, pojem, ki ga je utemeljil Vigotski. Proksimalni razvoj se nanaša na razliko med ravnjo učenja, ki ga lahko učenec doseže pri učenju sam, in (višjo) ravnjo, ki jo lahko doseže ob pomoči druge osebe (npr. učitelja). Ta pojem je še posebej pomemben $v$ situacijah, ko se učitelj odloča o svoji vlogi in nači$n u$ posredovanja $v$ samostojno učenje posameznika ali skupine. Ideje, ki sta jih razvijala Piaget in Vigotski (in so jih nadgradili številni kasnejši avtorji, npr. Yrjö Engeström s teorijo ekspanzivnega učenja, Etienne Bourgeois in Horst Siebert) v zvezi kognitivnim razvojem posameznika, so imele velik vpliv na razmišljanje o metodah poučevanja in organizaciji učnih dejavnosti, $v$ katerih ima učitelj osrednjo vlogo pri razlagi, vodenju diskusij in usmerjanju procesa učenja. 
Na podlagi teh in podobnih spoznanj se je $v$ preteklih letih $v$ didaktiki in pedagoški psihologiji uveljavila delitev metod na tiste, ki so bolj osredinjene na učitelja, in tiste, kjer je središče učenja udeleženec. To razlikovanje je bilo v izobraževanju odraslih hitro sprejeto, čeprav se tudi na tem področju pogosto uporabljajo tradicionalne metode poučevanja, ki v ospredje postavljajo učitelja. Po drugi strani pa na učenca osredinjene metode poučevanje upoštevajo potrebe učenca in njegovega učenja ter so najbrž tudi bolj v skladu z idejami učeče se družbe. Izobraževalne metode, ki omogočajo na učenca osredinjeno poučevanje, so bližje temeljnim idejam o izobraževanju, ki so se razvijale znotraj teorij izobraževanja odraslih in v katerih se je kot eno izmed glavnih razlik med izobraževanjem otrok in odraslih poudarjalo prav to, da so otroci bolj odvisni od odraslih kot njihovih učiteljev, medtem ko potrebujejo odrasli več avtonomije in samostojnosti.

Ne nazadnje pa je ob razmišljanju o metodah izobraževanja smiselno opozoriti še na povezanost med izobraževalnimi metodami, pristopi, oblikami itd. učenja, ki jih je učitelj izkusil ali bil z njimi seznanjen v času prejšnjega izobraževanja, in njegovo trenutno prakso. Mnogokrat se izkaže, da nauče$n i$ in priporočeni »pedagoško-andragoški pristopi« ne dosegajo pričakovanih rezultatov in mora učitelj poiskati svoje načine - najti svoj slog poučevanja. To pa lahko naredi samo v procesu stalnega strokovnega izobraževanja in samorefleksije.

$V$ prvem prispevku z naslovom »Razvijanje pismenosti v maternem jeziku, ko materni jezik ni uradni jezik: vpliv bralnih in pisnih praks« Maja Mezgec razmišlja o razvoju uradni jezik okolja, temveč manjšinski jezik.
$V$ članku se osredotoča predvsem na primer Slovencev $v$ Italiji in postavlja hipotezo, da so pripadniki manjšine, posebej tisti, ki so dokončali šolo z manjšinskim učnim jezikom, usvojili določen jezikovni standard in stopnjo funkcionalne pismenosti $v$ obeh jezikih, manjšinskem in večinskem. Poudarja pa tudi, da omejene možnosti rabe slovenščine v javnosti in skromna raba slovenščine na delovnem mestu močno omejujejo rabo in razvoj funkcionalne pismenosti $v$ slovenskem jeziku $v$ prid večinskemu italijanskemu jeziku.

Janez Skela v članku »Izkušnje z uporabo Evropskega jezikovnega listovnika (EJL) pri odraslih učencih v Sloveniji « predstavlja načela in cilje Evropskega jezikovnega listovnika (EJL), ki s svojo zasnovo spodbuja vseživljenjsko učenje tujih jezikov in krepi medkulturne izkušnje na vseh stopnjah učenja. Avtor opisuje nastanek EJL in njegov odnos do Skupnega evropskega jezikovnega okvira, v nadaljevanju pa dve osnovni funkciji EJL, njegovo zgradbo in vpliv, ki ga je EJL doslej imel na učenje in poučevanje tujih jezikov v Evropi in drugod. Prispevek sklene z obravnavo glavnih značilnosti slovenskega modela EJL za odrasle.

Izobraževalni pristopi in načini dela učiteljev s študenti $v$ visokošolskem izobraževanju so predstavljeni v prispevku »Izobraževalne metode in pristopi $v$ času študija in pridobljene kompetence v očeh študentov« Danijele Makovec in sodelavcev. V njem so avtorji želeli ugotoviti, kako študenti 1. in 3. letnika študija pedagogike iz Beograda ter pedagogike in andragogike iz Ljubljane ocenjujejo kakovost študija in kakšno je njihovo mnenje o njegovih posameznih vidikih. $V$ raziskavi so jih zanimala mnenja študentov o vsebini in strukturi študija, oblikah in metodah izobraževanja in študijskih gradivih ter kako ocenjujejo svojo usposo- 
bljenost za opravljanje bodočega poklica. Rezultati so pokazali, da so študenti obeh univerz prepoznali študijsko prakso oz. vaje kot ključne za razvoj strokovnih kompetenc. Med izobraževalnimi metodami, ki najbolj pripomorejo $k$ razvoju strokovnih kompetenc, pa so ljubljanski študenti višje ocenili predavanja, samostojni študij in hospitacije, srbski pa pomen raziskovalnega dela.

Čisto drugo ciljno skupino učečih se obravnava Petra Javrh v prispevku »Izobraževalni filmi kot del učnega gradiva za ranljive ciljne skupine «, v katerem nekatere teoretične poglede na učna gradiva za odrasle, predvsem tiste $v$ obliki video ali zvočnega zapisa, primerja z izkušnjami iz prakse slovenskih izobraževalcev ranljivih skupin odraslih s takimi didaktičnimi gradivi.

Širši razmislek o pomenu učenja odraslih in družbenih spremembah nam v branje ponuja Borut Mikulec. V besedilu, ki ga je naslovil »Družbene spremembe in vsě̌ivljenjsko učenje« analizira spremembe, ki jih prinašajo procesi globalizacije, kapitalizem, individualizem in pozna moderna. Na podlagi teh sprememb pojasnjuje premik $v$ politiki izobraževanja odraslih, za katerega je odgovorna država in je v funkciji demokratizacije družb, v politiko vseživljenjskega učenja kot pripravo odraslih za potrebe trga dela, kjer so odrasli sami odgovorni za svoj razvoj in življenjske izbire. Ob tako razumljeni politiki vseživljenjskega učenja se sprašuje, ali je mogoča emancipacija odraslih onkraj zahtev trga po lastnem opolnomočenju.

$V$ strokovnem prispevku »Nacionalna energetska pot Slovenija kot interaktivna metoda učenja « Bojan Žnidaršič predstavlja inovacijo neformalnega izobraževanja odraslih na področju učinkovite rabe energije in obnovljivih virov energije. To je Nacionalna energetska pot Slovenija, ki $z$ različnimi viri informacij sledi sodobnim spoznanjem o učenju odraslih, kar omogoča postopno in individualizirano konstruiranje znanja in na podlagi tega informirano odločanje. Avtor meni, da je tovrstno izobraževanje odlična priložnost za združevanje nekomercialnega in brezplačnega svetovanja ter izkušenj lastnikov ali upravljavcev energetsko učinkovitih objektov.

Predstavitev različnih oblik in metod izobraževanja odraslih zaključuje prispevek Dušane Findeisen z naslovom »O povezljivosti elementov različnih načinov učenja, metod in znanja «. Avtorica uvodoma predstavi, kako različni teoretiki izobraževanja odraslih obravnavajo metode, nato pa preučuje vrednost in povezljivost posameznih elementov »učenja s poskusi in napakami« in »nedirektivnega učenja«. Tako kot so metode eklektične, razmišlja avtorica, so lahko eklektični tudi načini učenja. Avtorica ilustrira svojo hipotetično trditev $z$ analizo »antimetode « francoskega režiserja Mauricea Pialata in jo primerja z metodami, kjer sta cilj in pot do cilja vnaprej postavljena. Avtorica opozarja na to, da je tudi učenje veščin povezano z učenjem o tem, »kako biti«, in nazadnje tudi, da metoda ne more služiti vsiljevanju znanja in resnice, saj se tako rušijo okoliščine, ki omogočajo pridobivanje ali ustvarjanje znanja.

$V$ tokratnem intervjuju se je Petra Javrh pogovarjala z Ido Srebotnik, novo predsednico Andragoškega društva Slovenije in dobitnico državnega priznanja za posebne dosežke $v$ izobraževanju odraslih za leto 2013. V pogovoru je razkrila svoje osebne poglede na pomen izobraževanja odraslih $v$ sedanjem trenutku in se ozrla $v$ zgodovino začetkov tega področja $v$ Sloveniji. 
Sabina Jelenc Krašovec poroča o udeležbi na 7. evropski konferenci ESREA z naslovom »Changing configurations of adult education in transitional times «, ki je bila med 4. in 7. septembrom 2013 v Berlinu. Na konferenci je tekla beseda o vlogi in razvoju izobraževanja odraslih na nacionalni in evropski ravni v tranzicijskih časih.

Tokratno številko zapiramo s predstavitvijo knjige »Funkcionalna pismenost $v$ manjšinskem jeziku: primer slovenske manjšine v Italiji « avtorice Maje Mezgec, ki je nastala na temelju empirične raziskave in poglobljenega študija znanstvene literature ter tudi izkustvenega poznavanja dvojezičnega prostora.

Marko Radovan Marho Radrevar 